\title{
The Efficacy of Tocilizumab for Takayasu Arteritis: Review of the Literatures
}

\author{
Nesibe Karahan Yeşil1', Hatice Şahin², Metin Işik ${ }^{3}$, Ziyaeddin Aktop4, İsmail Doğan5, \\ Ali Erdem Baki6 \\ ${ }^{1}$ Department of Rheumatology, Ankara Research and Education Hospital, Ankara, Turkey \\ ${ }^{2}$ Division of Rheumatology, Department of Internal Medicine, Faculty of Medicine, Bülent Ecevit University, \\ Zonguldak, Turkey \\ ${ }^{3}$ Division of Rheumatology, Department of Internal Medicine, Faculty of Medicine, Mevlana University, Konya, \\ Turkey \\ ${ }^{4}$ Department of Cardiology, Bülent Ecevit University, Zonguldak, Turkey \\ ${ }^{5}$ Division of Rheumatology, Department of Internal Medicine, Çorum Hitit University, Çorum, Turkey \\ ${ }^{6}$ Department of Physical Medicine and Rheabilitation, Bülent Ecevit University, Zonguldak, Turkey \\ Email: *metin1721978@yahoo.com
}

Received 14 September 2015; accepted 30 October 2015; published 2 November 2015

Copyright (C) 2015 by authors and Scientific Research Publishing Inc.

This work is licensed under the Creative Commons Attribution International License (CC BY).

http://creativecommons.org/licenses/by/4.0/

(c) (i) Open Access

\section{Abstract}

Takayasu arteritis is a large vessel vasculitis of the young women with giant cells and granuloma formation. The diagnosis and management of the disease are really not so easy because of the insidious onset and the difficulties in assessment of disease activity. Nearly $60 \%$ of the patients are corticosteroid resistant or dependent and relapses are very frequent during taper of the dose [1]. The novel biologic agents as Anti-TNF, Rutiximab and Tocilizumab provide acceptable response rates with low toxicity. Herein, we reviewed the efficacy of Tocilizumab in Takayasu arteritis.

\section{Keywords}

Takayasu Arteritis, Tocilizumab, Corticosteroid

\section{Introduction}

Takayasu Arteritis (TA) and Giant Cell Arteritis are the two main causes of Large Vessel Vasculitis (LVV) [1]. Nearly $90 \%$ of the patients are female. TA is usually diagnosed before 40 and both the disease and the treatment used to manage the disease lead premature mortality and also significant morbidity. Stenosis and occlusion of

${ }^{*}$ Corresponding author.

How to cite this paper: Yeşil, N.K., Şahin, H., Işik, M., Aktop, Z., Doğan, I. and Baki, A.E. (2015) The Efficacy of Tocilizumab for Takayasu Arteritis: Review of the Literatures. Open Journal of Rheumatology and Autoimmune Diseases, 5, 118-125.

http://dx.doi.org/10.4236/ojra.2015.54019 
vessels may cause tissue ischemia and aneurysms may cause rupture, which are the main complications of the disease. Sometimes systemic manifestations as fever, malaise, weight loss, night sweats, polyarthralgia or arthritis may also present at time disease onset. TA is an uncommon disease and diagnosis of the disease may be done with a comprehensive history and a meticulous physical examination [2]. Especially pulses and 4 extremity blood pressure assessments are extremely important as well as listening the bruits and aortic murmur. TA may progress silently; therefore, clinical evaluation is sometimes unreliable. Furthermore, other than vasculitis, fibrosis may also lead to stenosis or occlusion and also uncontrolled hypertension may cause aneurysms [3]-[7]. The acute phase reactants are also unreliable for both diagnosis and follow-up and are not useful for deciding relapse and remission. Vascular imaging techniques are helpful for defining the anatomy of the vessels but are not reliable for describing the degree of inflammation, and therefore should not be used only criteria for tailoring immunosuppressive therapy. Glucocorticoids have lots of adverse effects but are the cornerstone of the therapy in TA. As steroid sparing agents both conventional and biologic disease modifying anti rheumatic agents are preferred but trials for efficacy of these agents are inefficient [8]-[10].

Herein, we reviewed the clinical and pathological aspects of TA and also tried to describe where the interleukin 6 blockers are placed in the management of TA.

\section{Classification of Arteritis}

According to the 2012 Revised International Chapel Hill Consensus Conference Nomenclature of Vasculitides there are 7 types of vasculitis and TA is a member of the LVV family (Table 1) [11]. On the other hand, the 1990 diagnostic criteria for TA (Table 2) were revised in 2010 by Ozen et al. (Table 3) [12]. Radiologic evaluation with conventional angiography or angiography with MRI or CT became the main diagnostic criteria and in the near future perhaps PET CT will be used more frequently in diagnosis. Other than the mandatory criterion

Table 1. 2012 revised international chapel hill consensus conference nomenclature of vasculitides.

\begin{tabular}{|c|c|}
\hline Type of vasculitis & Included vasculitis \\
\hline Large vessel vasculitis (LVV) & $\begin{array}{l}\text { Takayasu arteritis (TAK) } \\
\text { Giant cell arteritis (GCA) }\end{array}$ \\
\hline Medium vessel vasculitis (MVV) & $\begin{array}{l}\text { Polyarteritis nodosa (PAN) } \\
\text { Kawasaki disease (KD) }\end{array}$ \\
\hline Small vessel vasculitis (SVV) & $\begin{array}{l}\text { Antineutrophil cytoplasmic antibody (ANCA)-associated vasculitis (AAV) } \\
\text { Microscopic polyangiitis (MPA) } \\
\text { Granulomatosis with polyangiitis (Wegener’s) (GPA) } \\
\text { Eosinophilic granulomatosis with polyangiitis (Churg-Strauss) (EGPA) } \\
\text { Immune complex SVV } \\
\text { Anti-glomerular basement membrane (anti-GBM) disease } \\
\text { Cryoglobulinemic vasculitis (CV) } \\
\text { IgA vasculitis (Henoch-Schönlein) (IgAV) } \\
\text { Hypocomplementemic urticarial vasculitis (HUV) (anti-C1q vasculitis) }\end{array}$ \\
\hline Variable vessel vasculitis (VVV) & $\begin{array}{l}\text { Behcet's disease (BD) } \\
\text { Cogan's syndrome (CS) }\end{array}$ \\
\hline Single-organ vasculitis (SOV) & $\begin{array}{l}\text { Cutaneous leukocytoclastic angiitis } \\
\text { Cutaneous arteritis } \\
\text { Primary central nervous system vasculitis } \\
\text { Isolated aortitis } \\
\text { Others }\end{array}$ \\
\hline Vasculitis associated with systemic disease & $\begin{array}{l}\text { Lupus vasculitis } \\
\text { Rheumatoid vasculitis } \\
\text { Sarcoid vasculitis } \\
\text { Others }\end{array}$ \\
\hline Vasculitis associated with probable etiology & $\begin{array}{l}\text { Hepatitis C virus-associated cryoglobulinemic vasculitis } \\
\text { Hepatitis B virus-associated vasculitis } \\
\text { Syphilis-associated aortitis } \\
\text { Drug-associated immune complex vasculitis } \\
\text { Drug-associated ANCA-associated vasculitis } \\
\text { Cancer-associated vasculitis } \\
\text { Others }\end{array}$ \\
\hline
\end{tabular}


Table 2. 1990 criteria for the classification of Takayasu arteritis.

1) Age at disease onset $<40$ years

2) Claudication of extremities

3) Decreased brachial artery pulse

4) BP difference $>10 \mathrm{~mm} \mathrm{Hg}$

5) Bruit over subclavian arteries or aorta

6) Arteriogram abnormality
Development of symptoms or findings related to Takayasu arteritis at age $<40$ years

Development and worsening of fatigue and discomfort in muscles of 1 or more extremity while in use, especially the upper extremities

Decreased pulsation of 1 or both brachial arteries

Difference of $>10 \mathrm{~mm} \mathrm{Hg}$ in systolic blood pressure between arms

Bruit audible on auscultation over 1 or both subclavian arteries or abdominal aorta

Arteriographic narrowing or occlusion of the entire aorta, its primary branches, or large arteries in the proximal upper or lower extremities, not due to arteriosclerosis, fibromuscular dysplasia, or similar causes; changes usually focal or segmental

${ }^{*}$ For purposes of classification, a patient shall be said to have Takayasu arteritis if at least 3 of these 6 criteria are present. The presence of any 3 or more criteria yields a sensitivity of $90.5 \%$ and a specificity of $97.8 \%$. BP = blood pressure (systolic; difference between arms).

\section{Table 3. The EULAR/PRINTO/PRES criteria for childhood Takayasu arteritis.}

\begin{tabular}{ll}
\hline \multicolumn{1}{c}{ Criterion } & \multicolumn{1}{c}{ Definition } \\
\hline Angiographic abnormality (mandatory criterion) & $\begin{array}{l}\text { Angiography (conventional, computed tomography, or magnetic resonance } \\
\text { imaging) of the aorta or its main branches and pulmonary arteries showing } \\
\text { aneurysm/dilatation, narrowing, occlusion or thickened arterial wall not due to } \\
\text { fibromuscular dysplasia, or similar causes; changes usually focal or segmental }\end{array}$ \\
Pulse deficit or claudication & $\begin{array}{l}\text { Lost/decreased/unequal peripheral artery pulse(s) } \\
\text { Claudication: focal muscle pain induced by physical activity }\end{array}$ \\
Blood pressure discrepancy & $\begin{array}{l}\text { Discrepancy of four limb systolic blood pressure }>10 \text { mmHg difference in } \\
\text { any limb }\end{array}$ \\
Bruits & $\begin{array}{l}\text { Audible murmurs or palpable thrills over large arteries } \\
\text { Systolic/diastolic blood pressure greater than 95th percentile for height }\end{array}$ \\
Acute phase reactants & $\begin{array}{l}\text { Erythrocyte sedimentation rate }>20 \text { mm per first hour or C-reactive protein any } \\
\text { value above normal (according to the local laboratory) }\end{array}$
\end{tabular}

TA is classified when the mandatory criterion is present plus any other criteria.

there are 4 criteria related to a meticulous physical examination; control of the arterial pulses, assessment of 4 extremity blood pressure and listening to the murmurs. The last criterion is the laboratory evaluation of acute phase reactants.

Direct pathologic evaluation of the Aorta by biopsy seems to be more reliably in assessment of inflammation but this procedure is uneasy and has a high complication rate. Therefore for only rare and complicated cases biopsy may be done but for routine diagnosis biopsy is never preferred. Hata et al. have classified TA according to the radiologic findings (Table 4) [3].

\section{Clinical Features of TA}

There are main clinical features in TA as hemiparesis, headache, dizziness, seizures, visual changes, aphasia, syncope, constitutional symptoms, limp claudication and elevation of CRP and/or ESR.

Nearly half or the patients have neurological symptoms including headache, dizziness, visual disturbances, convulsive crisis, transient ischemic attack, stroke and posterior reversible encephalopathy syndrome. Both ischemic and embolic complications may be reported with TA and to our knowledge neurologic symptoms are more closely related to type 1 TA [13]. Elevated and uncontrolled hypertension, sometimes asymmetric, may also increase the incidence of the neurologic symptoms therefore routine blood pressure control and, if necessary, effective treatment is the ideal management strategy. For patients with elevated or uncontrolled hypertension renal arterial involvement should also be kept in mind. Limp claudication develops by time but may limit daily activities. Elevated CRP and/or ESR are not routine findings but may reflect the degree of inflammation and also may guide the therapy. At the onset of the disease fever, weight loss, fatigue, malaise, myalgia and arthralgia are frequent as a result of systemic inflammation [14]-[16]. 
Table 4. Radiologic classification of TA by Hata et al.

\begin{tabular}{cc}
\hline Typology of vascular involvement & Definition \\
\hline Type 1 & Involvement of the branches of the aortic arch \\
Type $2 \mathrm{a}$ & Involvement of the ascending aorta, aortic arch and its branches \\
Type $2 \mathrm{~b}$ & Type 2a plus involvement of thoracic descending aorta \\
Type 3 & Involvement of thoracic descending aorta, abdominal aorta and/or renal arteries \\
Type 4 & Involvement of abdominal aorta and/or renal arteries \\
Type 5 & IIb plus type IV \\
\hline
\end{tabular}

Arterial inflammation may lead to headache, thoracic pain, and carotidynia. Furthermore, the clinical symptoms associated to arterial compromise (abdominal and cardiac angina, heart failure, dizziness, symptoms from an enlarging aneurysm, dissection, transient ischemic attack, or stroke) may also occur frequently [16].

\section{Pathology and Immunologic Mechanisms in TA}

TA is a type of primary and granulomatous large vessel vasculitis of unknown origin. Some studies have showed the association between HLABw52 and HLA-B39.2 suggesting an immune-genetic predisposition [17]. The etiology of TA is still unknown but infectious agents, and genetic factors are blamed in the pathogenesis of this disease [18]-[20]. Furthermore, the role of cell-mediated autoimmunity has also been defined in the pathogenesis of TA. Previous studies have showed the infiltration by macrophages, CD4+ T cells, CD8+ T cells, $\gamma \delta \mathrm{T}$ cells, natural killer (NK) cells and neutrophils in the aortic wall [17]. Pryshchep et al. have studied the expression profile of Toll-like receptors (TLR) 1 to 9, and reported that TLR2 and TLR4 were always present, TLR7 and TLR9 infrequent, and TLR1, TLR3, TLR5, TLR6, and TLR8 were differentially expressed, meaning that there is a specific pattern of vascular involvement in TA, and TLR signatures are the major determinants of this pattern [21]. Pryshchep et al. have also defined that the adventitia in TA contains T-cells co-localizing with Dentritic Cells. Seko et al. have shown that NK cells release perforin directly onto the surface of arterial vascular cells and lead to vascular injury and $\gamma \delta$ T cells trigger apoptosis of vascular cells in TA [17]. Mycobacterial heat-shock proteins (HSP) are blamed for the stimulus that drives these immune responses and molecular mimicry may occur between a host and a microbial heat-shock protein [22]. After the activation of DC, CD4+ TH 1 cells are activated which stimulates the macrophages for secretion of IL-1, 6, 23, tumor necrosis factor alpha and tissue growth factor Beta. By these cytokines TH17 cells are activated and the cytokine, IL-17, released from these cells activate the neutrophils. Furthermore, vascular endothelial growth factor (VEGF) and platelet derived growths factor (PDGF) lead to neovascularization and also intimal proliferation.

\section{Management of TA}

Corticosteroids are the mainstay of therapy for active TA and the classic approach has been prednisone 40 - 60 $\mathrm{mg} /$ day $(1 \mathrm{mg} / \mathrm{kg} /$ day) for about a month, and then reducing the dose by $2.5-5 \mathrm{mg} /$ week until $10-20 \mathrm{mg} / \mathrm{day}$ is reached [23]. Maksimowicz-McKinnon et al. reported 75 patients with TA in an American cohort and reported that glucocorticoids induced remission in about $60 \%$ of patients, but relapses occurred in the majority $(>50 \%)$ of the patients during steroid taper. Other studies also state that disease control with only prednisone is inadequate ( $\leq 20 \%$ patients), and nearly three fourths (66\% - 84\%) need other immunosuppressive agents [23]-[25]. Another limitation for the glucocorticoid therapy is the adverse effects, meaning that additional medications to counteract the side effects of glucocorticoids may be necessary.

Methotrexate, azathioprine, mycophenolate mofetil, leflunomide, and cyclophosphamide are the most widely used and studied corticosteroid sparing agents. For relapses usually steroid dose is increased and methotrexate or azathioprine is added to the therapy protocol. Mycophenolate mofetil and cyclophosphamide are considered for resistant patients or for patients with life threatening complications.

Aspirin was shown to decrease the ischemic events in a small study. Effective control of hypertension is extremely important, because uncontrolled hypertension is may be a sign of renal artery stenosis and may lead to 
encephalopathy, stroke, renal disease, retinopathy and congestive heart failure [26]-[30].

\section{Biologic Agents}

Giant cells and granuloma formation take place in the pathogenesis of TA meaning that $\mathrm{T}$ cells and antigenpresenting cells have a prominent role in the pathogenesis of TA. Tumor Necrosis Factor alpha (TNF alpha) is a product of the macrophages and T-cells, and is a critical cytokine in granuloma formation, activation of endothelial cells and enhancing platelet adhesion. Therefore, for patients with resistant diseases TNF alpha inhibitors have been used. Etanercept and Infliximab are the two Anti-TNF agents studied for TA and the results were encouraging. Tapering the dose and also discontinuation of corticosteroid therapy was able with these two antiTNF agents and also the relapse rates were lower. On the other hand, relapses under anti-TNF agents were treated with increase of the anti-TNF dose. Hoffman et al. reported 67\% long term steroid free remission with anti-TNF agents. Similarly Moloy et al. reported 60\% steroid free long term remission. Quartuccio et al. have reported the longest follow-up duration with infliximab in TA and reported $73.3 \%$ remission. Totally, to our knowledge, more than 120 patients with TA have been treated with anti-TNF agents [31]-[33].

Formerly, TA was defined to be a T cell mediated disease but recently the role of B cells was well defined and some resistant patients were treated with Rutiximab and 5 of these 6 patients achieved remission. Currently, a randomized controlled trial using abatacept is ongoing [34].

\section{Tocilizumab}

Interleukin 6 is a pro-inflammatory cytokine and is secreted by monocytes/macrophages and lymphocytes. This cytokine may activate hematopoietic cells, stimulate acute phase protein production in the liver, stimulates maturation of B cells into antibody-secreting plasma cells and T cells toward a Th17 phenotype. IL-6 also acts as a migration factor to draw inflammatory cells in to the tissue. Tocilizumab is a recombinant, humanized monoclonal antibody against the IL-6 receptor. Tocilizumab mainly functions by binding soluble and membrane bound IL-6 receptors and then prevents IL-6 attachment and signaling. The expression of IL-6 is known to be increased in the aortic wall in TA and the serum levels correlate with disease activity. These data show that IL-6 is a good potential treatment target in TA.

Thus far, there are 44 TA patients treated with tocilizumab. In 2013 Unizony et al., reviewed 9 of these patients [35]. Later in 2014 Clifford et al. reviewed totally 17 patients in the literature. All 17 patent responded tocilizumab well, and only 3 relapses were reported. All the patients were able to taper steroid doses but only $31 \%$ could discontinue. Of all, $78 \%$ have radiological improvement and the $20 \%$ have adverse effects [36]. Abisror et al. have collected all the abstracts and reported totally 44 TA patients treated with Tocilizumab [37]. To this largest review the clinical response was $75 \%$ and only 7 relapses were reported. Interestingly, PET CT was the most frequently used radiologic modality (12/17). Majority of the patients received $8 \mathrm{mg} / \mathrm{kg} / \mathrm{month}$ of Tocilizumab. The median follow up was 15 months and the mean prednisone dose was tapered from $15 \mathrm{mg}$ to $5 \mathrm{mg}$. there were 14 patients previously treated with anti-TNF agent and $69 \%$ of them also achieved clinical and $71 \%$ achieved laboratory response.

To the literature, Tocilizumab appears to be very effective for resistant TA patients. Seventeen cases have been fully published and all achieved clinical response. A 78\% radiologic improvement with acceptable adverse effects (one viral infection, one liver enzyme elevation and one episode of neutropenia) is of course encouraging. Furthermore, we should not forget that all these cases were resistant to multiple immunosuppressive agents and 8 were resistant to anti-TNF agents [36].

On the other hand, the number of patients is still very low and the median follow up period is very short. As stated before laboratory parameters are not reliable in assessment of disease activity, radiologic modalities and clinical assessment are more important. But to the literature there are some patients followed without any radiologic tests therefore all these results may be misleading. The aortic wall thickness is also not a reliable marker but a new stenotic or aneurysmal lesion especially in an unaffected part of the aorta or branches provide the most convincing evidence of active disease.

Furthermore, the autopsy data from giant cell arteritis patients who were believed to be under remission showed ongoing inflammatory infiltrates in the large vessels therefore the symptomatic improvement with tocilizumab in TA may not mean real remission. 


\section{Conclusions}

Takayasu arteritis is one of the large vessel vasculitis with multiple clinical manifestations and insidious onset. The diagnosis and the management of the disease, as well as follow up, have different difficulties. One of the most important difficulties in management is the high resistance and relapse rates and continuous corticosteroid necessity. The novel biologic agents as anti-TNFs, Rutiximab and Tocilizumab provide effective and relatively safe treatment options. Tocilizumab as an IL-6 antagonist is a novel anti-inflammatory agent in rheumatology and the experience with this agent is limited. On the other hand, the present data encourage the clinicians for further trials and the high response rates are also pleasing.

In conclusion, Tocilizumab may be the first biologic alternative for TA patients resistant to classic immunosuppressive agents.

\section{References}

[1] Maksimowicz-McKinnon, K., Clark, T.M. and Hoffman, G.S. (2009) Takayasu Arteritis and Giant Cell Arteritis: A Spectrum within the Same Disease? Medicine, 88, 221-226. http://dx.doi.org/10.1097/MD.0b013e3181af70c1

[2] Tso, E., Flamm, S.D., White, R.D., Schvartzman, P.R., Mascha, E. and Hoffman, G.S. (2002) Takayasu Arteritis: Utility and Limitations of Magnetic Resonance Imaging in Diagnosis and Treatment. Arthritis \& Rheumatology, 46, 16341642. http://dx.doi.org/10.1002/art.10251

[3] Hata, A., Noda, M., Moriwaki, R. and Numano, F. (1996) Angiographic Findings of Takayasu Arteritis: New Classification. International Journal of Cardiology, 54, S155-S163. http://dx.doi.org/10.1016/S0167-5273(96)02813-6

[4] Lupi-Herrera, E., Sanchez-Torres, G., Marcushamer, J., Mispireta, J., Horwitz, S. and Vela, J.E. (1977) Takayasu’s Arteritis. Clinical Study of 107 Cases. American Heart Journal, 93, 94-103. http://dx.doi.org/10.1016/S0002-8703(77)80178-6

[5] Arend, W.P., Michel, B.A., Bloch, D.A., Hunder, G.G., Calabrese, L.H., Edworthy, S.M., et al. (1990) The American College of Rheumatology 1990 Criteria for the Classification of Takayasu Arteritis. Arthritis \& Rheumatology, 33, 1129-1134. http://dx.doi.org/10.1002/art.1780330811

[6] Dabague, J. and Reyes, P.A. (1996) Takayasu Arteritis in Mexico: A 38-Year Clinical Perspective through Literature Review. International Journal of Cardiology, 54, S103-S109. http://dx.doi.org/10.1016/S0167-5273(96)88779-1

[7] Hall, S., Barr, W., Lie, J.T., Stanson, A.W., Kazmier, F.J. and Hunder, G.G. (1985) Takayasu Arteritis. A Study of 32 North American Patients. Medicine, 64, 89-99.

[8] Ishikawa, K. (1978) Natural History and Classification of Occlusive Thromboaortopathy (Takayasu’s Disease). Circulation, 57, 27-35. http://dx.doi.org/10.1161/01.CIR.57.1.27

[9] Koide, K. (1992) Takayasu Arteritis in Japan. Heart Vessels, 7, 48-54. http://dx.doi.org/10.1007/BF01744544

[10] Kimura, A., Kitamura, H., Date, Y. and Numano, F. (1996) Comprehensive Analysis of HLA Genes in Takayasu Arteritis in Japan. International Journal of Cardiology, 54, S61-S69. http://dx.doi.org/10.1016/S0167-5273(96)88774-2

[11] Takahashi, K., Oharaseki, T., Yokouchi, Y., Katsuzaki, J. and Enomoto, Y. (2014) Overview of the 2012 Revised International Chapel Hill Consensus Conference Nomenclature of Vasculitides (CHCC2012). Nihon Jinzo Gakkai Shi, 56, 70-79.

[12] Ozen, S., Pistorio, A., Iusan, S.M., Bakkaloglu, A., Herlin, T., Brik, R., et al. (2010) EULAR/PRINTO/PRES Criteria for Henoch-Schonlein Purpura, Childhood Polyarteritis Nodosa, Childhood Wegener Granulomatosis and Childhood Takayasu Arteritis: Ankara 2008. Part II: Final Classification Criteria. Annals of the Rheumatic Diseases, 69, 798-806. http://dx.doi.org/10.1136/ard.2009.116657

[13] Cong, X.L., Dai, S.M., Feng, X., Wang, Z.W., Lu, Q.S., Yuan, L.X., Zhao, X.X., Zhao, D.B. and Jing, Z.P. (2010) Takayasu's Arteritis: Clinical Features and Outcomes of 125 Patients in China. Clinical Rheumatology, 29, 973-981. http://dx.doi.org/10.1007/s10067-010-1496-1

[14] Cid, M.C., Font, C., Coll-Vinent, B. and Grau, J.M. (1998) Large Vessel Vasculitides. Current Opinion in Rheumatology, 10, 18-28. http://dx.doi.org/10.1097/00002281-199801000-00004

[15] Lupi, E., Sanchez, G., Horwitz, S. and Gutierrez, E. (1975) Pulmonary Artery Involvement in Takayasu's Arteritis. Chest, 67, 69-74. http://dx.doi.org/10.1378/chest.67.1.69

[16] Sharma, B.K., Jain, S. and Sagar, S. (1996) Systemic Manifestations of Takayasu Arteritis: The Expanding Spectrum. International Journal of Cardiology, 54, S149-S154. http://dx.doi.org/10.1016/S0167-5273(96)88784-5

[17] Seko, Y., Minota, S., Kawasaki, A., Shinkai, Y., Maeda, K., Yagita, H., et al. (1994) Perforinsecreting Killer Cell Infiltration and Expression of a 65-kd Heat-Shock Protein in Aortic Tissue of Patients with Takayasu's Arteritis. Journal of Clinical Investigation, 93, 750-758. http://dx.doi.org/10.1172/JCI117029 
[18] Kallenberg, C.G. and Tadema, H. (2008) Vasculitis and Infections: Contribution to the Issue of Autoimmunity Reviews Devoted to “Autoimmunity and Infection”. Autoimmunity Reviews, 8, 29-32. http://dx.doi.org/10.1016/j.autrev.2008.07.020

[19] Noris, M. (2001) Pathogenesis of Takayasu’s Arteritis. Journal of Nephrology, 14, 506-513.

[20] Lupi-Herrera, E., Sanchez-Torres, G., Marcushamer, J., Mispireta, J., Horwitz, S. and Vela, J.E. (1977) Takayasu’s Arteritis. Clinical Study of 107 Cases. American Heart Journal, 93, 94-103. http://dx.doi.org/10.1016/S0002-8703(77)80178-6

[21] Pryshchep, O., Ma-Krupa, W., Younge, B.R., Goronzy, J.J. and Weyand, C.M. (2008) Vessel-Specific Toll-Like Receptor Profiles in Human Medium and Large Arteries. Circulation, 118, 1276-1284. http://dx.doi.org/10.1161/CIRCULATIONAHA.108.789172

[22] Schultz, D.R. and Arnold, P.I. (1993) Heat Shock (Stress) Proteins and Autoimmunity in Rheumatic Diseases. Seminars in Arthritis and Rheumatism, 22, 357-374. http://dx.doi.org/10.1016/S0049-0172(05)80028-9

[23] Arnaud, L., Haroche, J., Toledano, D., Cacoub, P., Mathian, A., Costedoat-Chalumeau, N., et al. (2011) Cluster Analysis of Arterial İnvolvement in Takayasu Arteritis Reveals Symmetric Extension of the Lesions in Paired Arterial Beds. Arthritis \& Rheumatism, 63, 1136-1140. http://dx.doi.org/10.1002/art.30240

[24] Lv, N., Dang, A., Wang, Z., Zheng, D. and Liu, G. (2011) Association of Susceptibility to Takayasu Arteritis in Chinese Han Patients with HLA-DPB1. Human Immunology, 72, 893-896. http://dx.doi.org/10.1016/j.humimm.2011.05.001

[25] Flores-Dominguez, C., Hernandez-Pacheco, G., Zuniga, J., Gamboa, R., Granados, J., Reyes, P.A., et al. (2002) Alleles of the Major Histocompatibility System Associated with Susceptibility to the Development of Takayasu's Arteritis. Gaceta Médica de México, 138, 177-183.

[26] Vargas-Alarcon, G., Hernandez-Pacheco, G., Soto, M.E., Murguia, L.E., Perez-Hernandez, N., Granados, J., et al. Comparative Study of the Residues 63 and 67 on the HLA-B Molecule in Patients with Takayasu's Arteritis. Immunology Letters, 96, 225-229. http://dx.doi.org/10.1016/j.imlet.2004.08.009

[27] Yoshida, M., Kimura, A., Katsuragi, K., Numano, F. and Sasazuki, T. (1993) DNA Typing of HLA-B Gene in Takayasu's Arteritis. Tissue Antigens, 42, 87-90. http://dx.doi.org/10.1111/j.1399-0039.1993.tb02172.x

[28] Bertipaglia, B., Faggin, E., Cillo, U., Zanus, G., Angelini, A. and Pauletto, P. (2004) Is Apoptosis of Vascular Smooth Muscle Cells Involved in the Development of Takayasu Arteritis? Suggestions from a Case Report. Rheumatology, 44, 484-487. http://dx.doi.org/10.1093/rheumatology/keh515

[29] Seko, Y., Sugishita, K., Sato, O., Takagi, A., Tada, Y., Matsuo, H., et al. (2004) Expression of Costimulatory Molecules (4-1BBL and Fas) and Major Histocompatibility Class I Chain-Related A (MICA) in Aortic Tissue with Takayasu's Arteritis. Journal of Vascular Research, 41, 84-90. http://dx.doi.org/10.1159/000076437

[30] Vinay, D.S. and Kwon, B.S. (1998) Role of 4-1BB in Immune Responses. Seminars in Immunology, 10, 481-489. http://dx.doi.org/10.1006/smim.1998.0157

[31] Hoffman, G.S., Merkel, P.A., Brasington, R.D., Lenschow, D.J. and Liang, P. (2004) Anti-Tumor Necrosis Factor Therapy in Patients with Difficult to Treat Takayasu Arteritis. Arthritis \& Rheumatism, 50, 2296-2304. http://dx.doi.org/10.1002/art.20300

[32] Molloy, E.S., Langford, C.A., Clark, T.M., Gota, C.E. and Hoffman, G.S. (2008) Anti-Tumour Necrosis Factor Therapy in Patients with Refractory Takayasu Arteritis: Long-Term Follow-Up. Annals of the Rheumatic Diseases, 67, 15671569. http://dx.doi.org/10.1136/ard.2008.093260

[33] Quartuccio, L., Schiavon, F., Zuliani, F., Carraro, V., Catarsi, E., Tavoni, A.G., et al. (2012) Long-Term Efficacy and Improvement of Health-Related Quality of Life in Patients with Takayasu's Arteritis Treated with Infliximab. Clinical and Experimental Rheumatology, 30, 922-928.

[34] Caltran, E., Di Colo, G., Ghigliotti, G., Capecchi, R., Catarsi, E., Puxeddu, I., Migliorini, P. and Tavoni, A. (2014) Two Takayasu Arteritis Patients Successfully Treated with Rituximab. Clinical Rheumatology, 33, 1183-1184. http://dx.doi.org/10.1007/s10067-014-2506-5

[35] Unizony, S., Arias-Urdaneta, L., Miloslavsky, E., Arvikar, S., Khosroshahi, A., Keroack, B., Stone, J.R. and Stone, J.H. (2012) Tocilizumab for the Treatment of Large-Vessel Vasculitis (Giant Cell Arteritis, Takayasu Arteritis) and Polymyalgia Rheumatica. Arthritis Care \& Research, 64, 1720-1729. http://dx.doi.org/10.1002/acr.21750

[36] Clifford, A. and Hoffman, G.S. (2014) Recent advances in the Medical Management of Takayasu Arteritis: An Update on Use of Biologic Therapies. Current Opinion in Rheumatology, 26, 7-15. http://dx.doi.org/10.1097/BOR.0000000000000004

[37] Abisror, N., Mekinian, A., Lavigne, C., Vandenhende, M.A., Soussan, M. and Fain, O. (2013) Tocilizumab in Refractory Takayasu Arteritis: A Case Series and Updated Literature Review. Autoimmunity Reviews, 12, 1143-1149. http://dx.doi.org/10.1016/j.autrev.2013.06.019 


\section{Nomenclatures}

TA: takayasu arteritis

LVV: large vessel vasculitis

NK: natural killer

VEGF: vascular endothelial growth factor

PDGF: platelet derived growth factor

TNF: tumor necrosis factor

PET-CT: positron emission tomography

IL: interleukin 